\title{
Mustard Gas
}

National Cancer Institute

\section{Source}

National Cancer Institute. Mustard Gas. NCI Thesaurus. Code C44406.

A pale yellow, oily, highly toxic, volatile, liquid alkylating compound with a sweet to garliclike odor that evaporates to a poisonous gas. Mustard gas is a vesicant that was first used in chemical warfare in World War I, but is now only used in small amounts in research studies involving alkylating agents. Exposure to this substance is corrosive to the eyes, skin and lungs and leads to blindness and blistering of the skin and can cause severe and sometimes fatal respiratory damage. Mustard gas is a mutagen and is a known carcinogen that is associated with an increased risk of developing lung and other respiratory tract cancers. ( $\mathrm{NCl} 05)$ 